\title{
Pengaruh Pengungkapan Akuntansi Lingkungan dan Kepemilikan Saham Terhadap Nilai Perusahaan Melalui Kinerja Keuangan
}

\author{
Yuniep Mujiati Suaidah \\ STIE PGRI Dewantara Jombang \\ Korespondensi: yuniepmujatis@gmail.com
}

\begin{abstract}
abstrak
Penelitian ini bertujuan untuk menganalisis pengaruh pengungkapan akuntansi lingkungan dan kepemilikan saham terhadap nilai perusahaan melalui kinerja keuangan. Populasi dalam penelitian ini adalah perusahaan manufaktur yang terdaftar di BEI sub sektor kemasan dan plastik. Sampel berjumlah 9 perusahaan dengan menggunakan metode purposive sampling. Data yang diperoleh dalam penelitian ini yaitu berasal dari data sekunder yakni data yang terdapat di bursa efek indonesia. Teknik analisis data yang digunakan adalah Uji Asumsi Klasik. Hasil penelitian ini menunjukkan bahwa terdapat pengaruh pengungkapan akuntansi lingkungan dan kepemilikan saham terhadap nilai perusahaan melalui kinerja keuangan. Kinerja keuangan juga mampu memoderasi pengungkapan akuntansi lingkungan terhadap nilai perusahaan, dan juga kinerja keuangan mampu memoderasi kepemilikan saham terhadap nilai perusahaan. Karena itu, pengungkapan akuntansi lingkungan perlu dicantumkan ke dalam laporan keuangan agar nilai perusahaan semakin baik, selain itu komposisi kepemilikan saham perusahaan juga di jadikan faktor agar nilai perusahaan semakin baik
\end{abstract}

Kata Kunci: Kepemilikan saham, nilai perusahaan, Pengungkapan akuntansi lingkungan, Kinerja keuangan

\begin{abstract}
This study aims to analyze the effect of environmental accounting disclosures and share ownership on firm value through financial performance. The population in this study are manufacturing companies listed on the IDX packaging and plastic sub-sector. The sample amounted to 9 companies using the purposive sampling method. The data obtained in this study is derived from secondary data, namely data contained in the Indonesian stock exchange. The data analysis technique used is the Classical Assumption Test. The results of this study indicate that there is an effect of disclosure of environmental accounting and share ownership on the value of the company through financial performance. Financial performance is also able to moderate the disclosure of environmental accounting to the value of the company, and also financial performance is able to moderate share ownership of the value of the company. Therefore, disclosure of environmental accounting needs to be included in the financial statements so that the value of the company is getting better, besides the composition of the company's share ownership is also made a factor so that the value of the company is getting better

Keywords: Share ownership, company value, environmental accounting disclosure, financial performance
\end{abstract}

\section{A. PENDAHULUAN}

Saat ini, dunia tengah memasuki era revolusi industry 4.0, dimana segala hal sangat mengandalkan teknologi digital. Sebagai imbasnya, segala sisi kegiatan saat ini berjalan serba cepat dan instant, mulai dari hal yang paling kecil seperti konsumsi makanan hingga yang paling kompleks, semuanya mengandalkan kecepatan penyajian. Meskipun hal ini sangat membantu dan meningkatkan kualitas kehidupan, namun disisi lain, hal ini juga menimbulkan dampak negative antara lain semakin banyaknya sampah/limbah plastik. Apabila tidak ada upaya untuk mengelolah limbah yang ditimbulkan akibat proses produksi dari industri kemasan dan plastic, hal itu akan mengganggu lingkungan. Untuk itu, diperlukan pengelolaan lebih lanjut terhadap limbah yang dihasilkan, yang harus didukung semua pihak termasuk pencipta/produsen kemasan platik tersbut, melalui berbagai upaya salah satunya yakni melalui akuntansi lingkungan.

Akan tetapi banyak perusahaan yang mengabaikan aspek lingkungan, kebanyakan perusahaan menginginkan laba maksimal. Kegiatan dari perusahaan yakni kegiatan 
operasional mulai dari kegiatan produksi sampai barang jadi merupakan pertimbangan utama dalam memperoleh laba yang maksimal. Dengan adanya penjelasan tersebut maka untuk memaksimalkan laba tersebut, aspek hubungan kemanusiaan terkait lingkungan alam menjadi terabaikan sedangkan aspek tersebut sangat berpengaruh terhadap going cocern perusahaan baik secara langsung maupun tidak langsung, apabila terdapat hal yang mempengaruhi keberlangsungan perusahaan maka perusahaan akan mengeluarkan dana yang cukup tinggi (Ja'far dan Amalia, 2006). Selain itu adanya laporan keuangan menjadi hal yang penting bagi perusahaan dimana laporan keuangan memberikan gambaran mengenai keadaan perusahaan. Agar hal tersebut bisa dicapai diperlukan adanya pengungkapan yang jelas tentang data akuntansi dan informasi yang relevan (Ikhsan, 2008). Bila manfaat yang diperoleh dari pengungkapan itu lebih besar dibandingkan biaya yang dikeluarkan maka perusahaan akan mengungkapkan informasi tersebut (Anggraini, 2006).

Pengungkapan akuntansi lingkungan di negara berkembang termasuk negara Indonesia memang sangat kurang, keadaan ini disebabkan antara lain yakni lemahnya sanksi hukum di negara indonesia (Lindrianasari, 2007). Saat ini di Indonesia pengungkapan mengenai akuntansi lingkungan belum di atur secara jelas dalam standart akuntansi yang artinya pelaporan informasi lingkungan dalam laporan tahunan masih bersifat sukarela. Peraturan ini dijelaskan pada PSAK No 1, Tahun 2015, dalam peraturan ini menyatakan bahwa perusahaan menyajikan laporan terkait dengan pengelolaan lingkungan hidup.

Hansen (2015) menjelaskan adanya pengungkapan alokasi biaya terkait dengan lingkungan hidup dapat memberikan informasi yang berkaitan dengan pendistribusian biaya lingkungan untuk proses perbaikan bagi perusahaan. Selain itu pengungkapan akuntansi lingkungan juga berperan untuk keberlangsungan bagi perusahaan karena apabila perusahaan mengungkapkan biaya lingkungan ke dalam laporan keuangan maka dapat dijadikan keputusan bagi pihak internal untuk pengambilan keputusan dan juga peran bagi pihak eksternal untuk mempengaruhi keputusan dari stakeholder dan untuk menarik investor agar menanamkan modal di perusahaan. Pengungkapan akuntansi lingkungan tergolong baik apabila melaporkan realita dari jenis kegiatan yang dilakukan perusahaan. Friend (2005) mengungkapkan bahwa pengungkapan biaya lingkungan, pengalokasian biaya sesuai dengan aktifitas yang terkaitdengan akuntansi lingkungan bisa meningkatkan nilai perusahaan. Menurut Iqbal dan Assih (2013) dengan adanya pengungkapan akuntansi lingkungan maka investor akan tertarik dan bisa meningkatkan kepercayaan investor kepada perusahaan. Pengungkapan akuntansi lingkungan diartikansebagai informasi berdasarkan evaluasi manajemen. Dengan adanya pengungkapan akuntansi lingkungan akan berpengaruh bagi peningkatan nilai perusahaan, melalui pengungkapan akuntansi lingkungan informasi terkait lingkungan diungkapkan oleh perusahaan dan melalui pengungkapan citra perusahaan yang diperkirakan akan meningkat dan meningkatkan persepsi stakeholder,akan lebih meningkatkan nilai pemegang saham. Tujuan dari pengungkapan akuntansi lingkungan diantaranya yakni suatu alat manajemen lingkungan dan akuntansi lingkungan yakni untuk menjalin komunikasi bagi masyarakat (Ikhsan, 2013). Yang dimaksud sebagai alat manajemen lingkungan yakni untuk mengetahui efektif atau tidak biaya lingkungan. Data dari akuntansi lingkungan berfungsi untuk menjabarkan biaya pengelolaan lingkungan.

Menurut Environmental accounting Guidelines (2008) akuntansi lingkungan mengenai identifikasi atau pengelompokan biayamaupun manfaataktivitas konservasi lingkungan, penyediaan sarana atau cara denganmelalui pengukuran kuantitatif, serta meraih efektivitas dan efisiensi dari aktivitas konservasi lingkungan. Fungsi pengungkapan akuntansi lingkungan sendiri terbagi menjadi dua, yaitu internal dan eksternal. Fungsi internal perusahaan untuk mengatur biaya konservasi lingkungan dan menganalisis biaya lingkungan dengan manfaatnya serta meningkatkan efektivitas dan efisien aktivitas konservasi 
lingkungan terkait dengan keputusan yang dibuat. Fungsi eksternal memungkinkan sebuah perusahaan untuk mempengaruhi keputusan stakeholder, diantaranya yakni mitra bisnis, investor, dan masyarakat lokal. Dengan adanya pengungkapan akuntansi lingkungan diharapkan bisa meningkatkan akuntabilitas stakeholder.

Penelitian ini bertujuan untuk mengetahui Pengaruh Pengungkapan Akuntansi Lingkungan dan Kepemilikan Saham Terhadap Nilai Perusahaan Melalui Kinerja Keuangan. Diharapkan, hasil dari penelitian ini akan menjadi bahan masukan yang berarti bagi pihakpihak yang berkepentingan.

\section{B. TINJAUAN PUSTAKA}

\section{Teori Sinyal (Signalling Theory)}

K.R Subramanyam (2010) informasi yakni salah satu faktor yang penting bagi investor karena dalam informasi menyajikan sebuah keterangan keadaan dari perusahaan. Pengumuman informasi akuntansi lingkungan memberikan signal bahwa perusahaan memiliki prospek yang baik di masa mendatang sehinggga penanam modal tertarik untuk menanamkan modal nya di perusahaan, dengan demikian maka pasar akan bereaksi yang tercermin melalui perubahan dalam harga saham. Teori sinyal menjelaskan mengapa perusahaan mempunyai mempunyai dorongan untuk memberikan informasi laporan keuangan pada pihak eksternal. Dorongan perusahaan untuk memberikan informasi adalah karena terdapat informasi asimetri antara perusahaan dengan pihak luar karena perusahaan mengetahui lebih banyak mengenai perusahaan dan prospek yang akan datang daripada pihak luar.

\section{Nilai Perusahaan}

Nilai perusahaan merupakan kondisi dari suatu perusahaan, perkembangan yang dicapai oleh perusahaan selama beberapa tahun dan kepercayaan masyarakat kepada perusahaan. Apabila perusahaan mengalami peningkatan itu adalah bentuk prestasi yang diinginkan yang sesuai dengan keinginan pemiliknya, jika suatu perusahaan mengalami peningkatan maka nilai perusahaan juga akan meningkat dan setelah itu kesejahteraan pemilik juga akan meningkat.

\section{Pengaruh Pengungkapan Akuntansi Lingkungan dan Kepemilikan Saham Terhadap Nilai Perusahaan}

Dalam perusahaan pengungkapan akuntansi lingkungan memberikan pengaruh yang baik bagi perkembangan perusahaan maupun bagi nilai perusahaan, karena dengan adanya informasi kegiatan akuntansi lingkungan dari perusahaanmaka memicu investor tertarik untuk menanamkan dananya ke perusahaan dan juga akan meningkatkan kepercayaan investor kepada perusahaan, oleh sebab itu maka akan membuat citra perusahaan akan meningkat dan nilai perusahaan juga akan meningkat (Iqbal dan Assih, 2013).

Dengan adanya Kepemilikan Institusional maka mendorong pemilik untuk melakukan peningkatan kinerja perusahaan maka nilai perusahaan juga akan meningkat. Demikian dengan kepemilikan manajerial yang juga akan mendorong manajemen untuk meningkatkan kinerja dari perusahaan, setelah itu nilai perusahaan juga akan meningkat (Soebiantoro, 2007). Menurut Patricia (2014) menyatakan bahwa semakin besar kepemilikan institusi maka akan semakin besar dorongan dari institusi untuk mengawasi manajemen.

\section{Pengaruh pengungkapan akuntansi lingkungan terhadap nilai perusahaan dimoderasi oleh kinerja keuangan.}

Dengan adanya pengaruh pengungkapan akuntansi lingkungan mampu memoderasi pengungkapan akuntansi lingkungan terhadap nilai perusahaan. Penelitian Octavia, (2012) dengan judul pengaruh pengungkapan akuntansi lingkungan terhadap nilai perusahaan melalui kinerja keuangan. 
Penelitian yang dilakukan Gozhali, (2009) menyatakan bahwa struktur kepemilikan saham memiliki hubungan dengan kinerja keuangan. Semakin tinggi struktur kepemilikan maka semakin tinggi pula rasio return on assset dan sebaliknya.

\section{Kerangka Pemikiran}

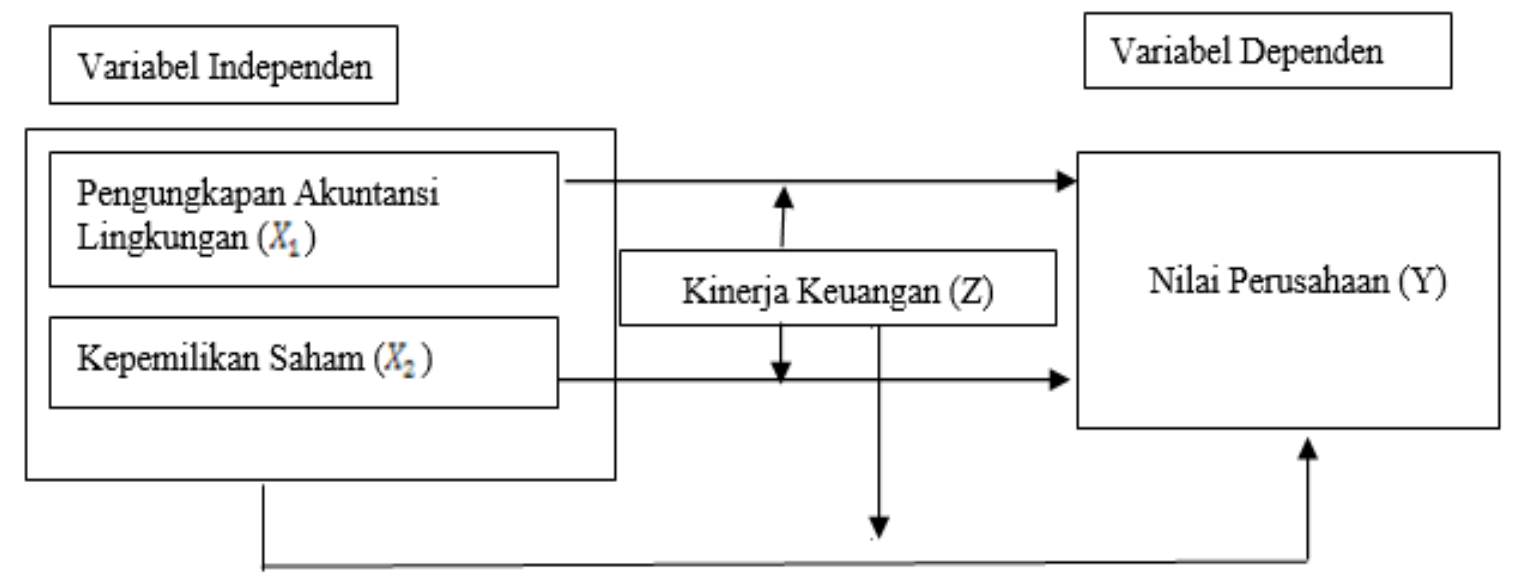

Gambaa 1: Kerangka Pemikiran

Berdasarkan kerangka pemikiran diatas, hipotesis yang dibangun pada penelitian ini adalah:

H1 : Pengungkapan akuntansi lingkungan berpengaruh terhadap nilai perusahaan

H2 : Kepemilikan saham berpengaruh terhadap nilai perusahaan

H3 : Pengungkapan akuntansi lingkungan berpengaruh terhadap nilai perusahaan dimoderasi oleh kinerja keuangan

H4 : Kepemilikan saham berpengaruh terhadap nilai perusahaan dimoderasi oleh kinerja keuangan

\section{METODE PENELITIAN}

\section{Rancangan Penelitian}

Penelitian ini membahas tentang pengaruh pengungkapan akuntansi lingkungan terhadap nilai perusahaan melalui kinerja keuangan pada perusahaan sub sektor plastik dan kemasan yang terdaftar di BEI penelitian ini merupakan penelitian kuantitatif.

Populasi dalam penelitian ini adalah laporan keuangan perusahaan sektor pengolaan plastik yang terdaftar di Bursa Efek Indonesia, yaitu sebanyak 14 perusahaan seperti pada tabel 2 (dua) berikut:

Tabel 2 Daftar Perusahaan

\begin{tabular}{llll}
\hline No & Kode Saham & Nama Emiten & Tanggal IPO \\
\hline 1. & AKKU & Alam Karya Unggul Tbk & 01Nov 2004 \\
\hline 2. & AKPI & Argha Karya Prima Industri Tbk & 18 Des 1992 \\
\hline 3. & APLI & Asiaplast Industries Tbk & 01 Mei 2000 \\
\hline 4. & BRNA & Berlina Tbk & 06 Nov 1989 \\
\hline 5. & FPNI & Lotte Chemical Titan & 21 Mar 2002 \\
\hline 6. & IGAR & Champion Pasific Indonesia Tbk & 05 Nov 1990 \\
\hline 7. & IPOL & Impack Pratama Industri Tbk & 17 Des 2014 \\
\hline 8. & SIAP & Sekawan Intipratama Tbk & 17 Okt2008 \\
\hline 9. & SIMA & Siwani Makmur Tbk & 03 Juni 1994 \\
\hline 10. & TRST & Trias Sentos Tbk & 02 July 1990 \\
\hline 11. & YPAS & Yana Prima HasTA Persada & 15 Mar2008 \\
\hline 12. & IMPC & Impack Pratama Industri Tbk & 17 Des 2017 \\
\hline 13. & PBID & Panca Budi Idaman Tbk & 13 Des 2017 \\
\hline 14. & TALF & Tunas Alfin Tbk & 12 Feb 2001 \\
\hline
\end{tabular}

Sumber: www.idx.co.id 
Selanjutnya, guna keperluan penelitian, diambil sampel dengan menggunakan metode purposive sampling dalam pengambilan data pada penelitian ini. Purposive sampling yakni suatu pengambilan sampel yang non random dan menentukan kriteria khusus yang sesuai dengan tujuan penelitian. Kriteria dalam penelitian ini adalah:

1. Perusahaan sub sektor kemasan dan plastik yang terdaftar di Bursa Efek Indonesia tahun 2015-2017

2. Perusahaan peserta PROPER (Program Penilaian Peringkat Kinerja Perusahaan Dalam Pengelolaan Lingkungan) yang terdaftar di Bursa Efek Indonesia

3. Perusahaan yang tercantum secara lengkap laporan keuangan selama periode 2015-2017 Maka berdasarkan kriteria diats, sampel yang terpilih dalam penelitian ini adalah:

Tabel 3: sampel penelitian

\begin{tabular}{|c|c|c|c|}
\hline No & Kriteria & $\begin{array}{l}\text { Jumlah } \\
\text { perusahaan }\end{array}$ & Kode Perusahaan \\
\hline 1 & $\begin{array}{l}\text { Perusahaan sub sektor kemasan dan plastik } \\
\text { yang terdaftar di BEI Tahun 2015-2017 }\end{array}$ & 14 & $\begin{array}{l}\text { IGAR, TRST, YPAS, } \\
\text { AKKU, APLI, BRNA, AKPI, SIMA, } \\
\text { SIAP, FPNI, IMPC, PBID, TALF , } \\
\text { IPOL }\end{array}$ \\
\hline 2. & $\begin{array}{l}\text { Perusahaan sub sektor kemasan dan plastik } \\
\text { yang tidak mengikuti PROPER }\end{array}$ & (5) & IPOL, PBID, TAIF, FPNI, IMPC \\
\hline 3. & $\begin{array}{l}\text { Perusahaan yang tidak mencantumkan } \\
\text { secara lengkap laporan keuangan tahun } \\
2015-2017\end{array}$ & (0) & \\
\hline 5. & Tahun pengamatan penelitian & 3 & $2015-2017$ \\
\hline 6. & $\begin{array}{l}\text { Jumlah sampel total selama periode } \\
\text { penelitian }\end{array}$ & 27 & \\
\hline
\end{tabular}

Dari tabel diatas, bisa disimpulkan bahwa jumlah populasi awal 14 perusahaan, setelah dilakukan seleksi pemilihan sampel sesuai kriteria yang ditetapkan maka memperoleh sampel penelitian sebanyak 9 perusahaan, sehingga jumalh sampel dalam penelitian ini adalah 27 laporan keuangan tahunan perusahaan sub sektor kemasan dan plastik selama periode 20152017 yang dipublikasikan di website www.idx.co.id

Setelah pemilihan sampel yang sesuai dengan kriteria yang ditentukan dalam penelitian ini dapat diperoleh 9 perusahaan yang akan dijadikan sampel yakni:

Tabel 4: Daftar Perusahaan Sampel

\begin{tabular}{lll}
\hline No & Nama Perusahaan & Kode Perusahaan \\
\hline 1. & Alam Karya Unggul Tbk & AKKU \\
\hline 2. & Argha Karya Prima Industri Tbk & AKPI \\
\hline 3. & Asiaplast Industries Tbk & APLI \\
\hline 4. & Sekawan Intipratama Tbk & SIAP \\
\hline 5. & Siwani Makmur Tbk & SIMA \\
\hline 6. & Trias Sentosa Tbk & TRST \\
\hline 7. & Yana Prima Hasta Persada & YPAS \\
\hline 8. & $\begin{array}{l}\text { Champion Pasific Indonesia } \\
\text { Kageo Igar Jaya Tbk }\end{array}$ & IGAR \\
\hline 9. & Berlina Tbk & \\
\hline Sumber: website www.idx.co.id & BRNA
\end{tabular}

Maka berdasarkan keterangan diatas, data yang digunakan dalam penelitian ini adalah data sekunder yang diperoleh secara tidak langsung dari pihak pertama, melainkan mengumpulkan data-data dari bursa efek indonesia tahun 2015-2017

\section{Teknik Analisis Data}

Pada penelitian ini teknik analisa data menggunakan statistik deskriptif, yaitu statistik yang digunakan untuk menganalisis data dengan cara mendeskripsikan suatu data yang sudah terkumpul (Sugiyono, 2013). Selanjutnya, untuk menguji hipotesis yang diajukan, digunakan Moderated Regression Analysis (MRA), Uji-T, dan Uji-F 


\section{HASIL PENELITIAN DAN PEMBAHASAN \\ 1. Hasil Statistik Deskriptif}

Dari hasil pengolahan data sekuder dengan alat bantu SPSS, diperoleh interpretasi statistic deskriptif, yang menunjukkan bahwa Nilai perusahaan (Y), dalam variabel nilai perusahaan nilai ratarata lebih besar daripada nilai standar deviasi 7,5719 > 1,671564 yang berarti bahwa nilai perusahaan memiliki sebaran yang baik.Pengungkapan akuntansi lingkungan (X1), Standar deviasi dari pengungkapan akuntansi lingkungan yakni 0,171801250. Kepemilikan saham (X2) memiliki nilai ratarata lebih kecil daripada standar deviasi 1,3322 < 1,6035002 yang berarti bahwa kepemilkan saham memiliki sebaran yang tidak baik, sedangkan untuk kinerja keuangan memiliki standar deviasi 0 , 6255.

\section{Uji Normalitas}

Menurut Gozali (2012) menyatakan bahwa Uji Normalitas bertujuan untuk menguji residual yang dibentuk model regresi linier terdistribusi normal,bukan variabel bebas ataupun variabel terikatnya, menggunakan Normal PP-Plot. Dengan pendekatan Normal P-Pplot dapat dilakukan dengan melihat sebaran titik-titik yang ada pada gambar. Apabila sebaran titik-titik tersebut mendekati atau rapat pada garis lurus (diagonal) maka dikatakan bahwa (data) residual terdistribusi normal, namu apabila sebaran titik-titik tersebut menjauhi garis maka tidak terdistribusi normal.

\section{Normal P-P Plot of Regression Standardized Residual}

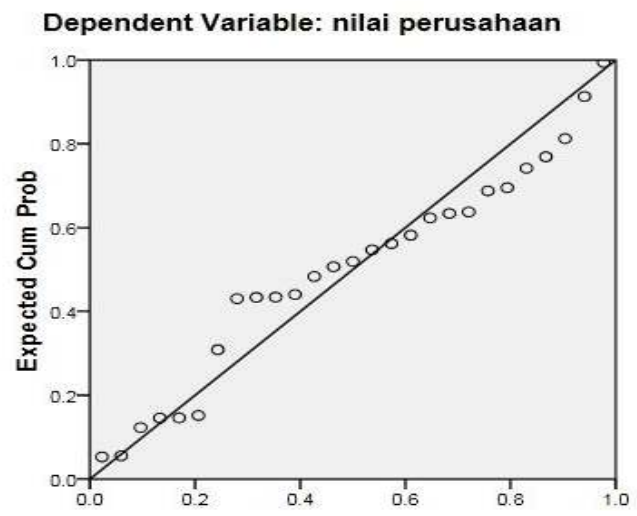

Gambar 2: Hasil Uji Normalitas

Sumber: Output SPSS data yang di olah, 2018

Berdasarkan gamabr diatas, diketahui bahwa grafik P-P Plot sebaran titik-titik mendekati garis, maka uji normalitas dengan menggunakan P-P plot mendekati atau rapat pada garis lurus (diagonal) dapat dikatakan bahwa (data) residual terdistribusi normal

\section{Uji Multikolinearitas}

Uji ini berfungsi untuk mengetahui hubungan yang terdapat antara variabel independen. Model regresi yang baik dimana tidak terjadi korelasi antara variabelnya. Pengujian ini menggunakan nilai VIF $<10$ maka terdapat nultikolinearis yang tidak dapat ditoleransi.

\section{Tabel 5: Hasi Uji Multikolinearitas}

Coefficientsa

\begin{tabular}{|c|c|c|c|c|c|c|c|}
\hline \multirow[b]{2}{*}{ Model } & & $\begin{array}{l}95 \% \\
\text { Confidence } \\
\text { Interval for B }\end{array}$ & \multicolumn{3}{|c|}{ Correlations } & \multicolumn{2}{|c|}{ Collinearity Statistics } \\
\hline & & Upper Bound & Zero-order & Partial & Part & Tolerance & VIF \\
\hline \multirow[t]{6}{*}{1} & (Constant) & 6.572 & & & & & \\
\hline & $\begin{array}{l}\text { pengungkapan akuntansi } \\
\text { lingkungan }\end{array}$ & 839.951 & .193 & .515 & .391 & 631 & 1.584 \\
\hline & kepemilikan saham & 12.876 & .457 & .685 & .613 & .541 & 1.849 \\
\hline & moderasi1 & -486.819 & -310 & -.437 & -.316 & .174 & 5.741 \\
\hline & moderasi2 & -30.347 & -.134 & -.520 & -.397 & .418 & 2.392 \\
\hline & kinerja keuangan & 4232.739 & -.260 & .449 & .327 & 154 & 6.473 \\
\hline
\end{tabular}

a. Dependent Variable: nilai perusahaan

Sumber: Output SPSS data yang di olah, 2018 
Berdasarkan tabel 5 (lima) uji multikolinearitas nilai dari VIF pada hasil output SPSS menunjukkan nilai dibawah 10, hal ini menunjukkan bahwa model regresi uji multikolinearitas baik atau memenuhi uji multikolinearitas.

\section{Uji Autokorelasi}

Uji autokorelasi bertujuan untuk mengetahui apakah dalam suatu model regresi linier terdapat korelasi antara pengganggu pada periode $\mathrm{t}$ dengan kesalahan pada periode $\mathrm{t}-1$, uji ini muncul akibat observasi yang berurutan sepanjang waktu yang berkaitan dengan satu sama lain dapat digunakan pada data yang bersifat time series ditemukan masalah autokorelasi.

Tabel 6: Hasil Uji Autokorelasi

\begin{tabular}{|c|c|c|c|c|c|c|c|c|}
\hline \multicolumn{9}{|c|}{ Model Summary } \\
\hline \multirow[b]{2}{*}{ Mode } & \multirow[b]{2}{*}{$\mathrm{R}$} & \multirow[b]{2}{*}{ R Square } & \multirow[b]{2}{*}{$\begin{array}{l}\text { Adjusted R } \\
\text { Square }\end{array}$} & \multirow[b]{2}{*}{$\begin{array}{l}\text { Std. Error of } \\
\text { the Estimate }\end{array}$} & \multicolumn{4}{|c|}{ Change Statistics } \\
\hline & & & & & $\begin{array}{l}\text { R Square } \\
\text { Change }\end{array}$ & F Change & df1 & $d f 2$ \\
\hline 1 & $.759 \mathrm{a}$ & .576 & .475 & $1.21072427 \mathrm{E} 2$ & .576 & 5.712 & 5 & 21 \\
\hline
\end{tabular}

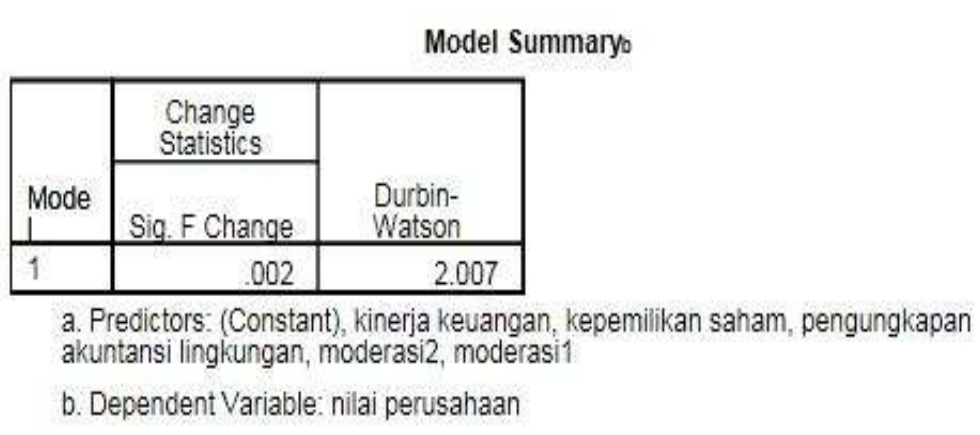

Sumber : Output SPSS data yang di olah, 2018

Berdasarkan tabel diatas penelitian ini mempunyai jumlah sampel dan jumlah variabel independen masing-masing sebesar 27 dan 2. Pada tabel 4.4 tabel durbin watson jumlah sampel dan variabel independen tersebut dapat memberikan informasi mengenai nilai DU dan DL, masing-masing sebesar 1,56 dan 1,24 sedangkan nilai 4-du sebesar 2,44. Nilai DW pada hasil SPSS tersebut berada diantara nilai DU hingga 4-du. Sehingga model regresi terbebas dari masalah autokorelasi.

\section{Uji Koefisien Determinasi}

Uji koefisien determinasi pada intinya mengukur seberapa jauh kemampuan model dalam menerangkan variabel-variabel dependen. Nilai $R^{2}$ yang mendeteksi 1 berarti variabelvariabel independen yang memberikan hampir semua informasi yang dibutuhkan untuk memprediksi variabel dependen. Uji ini digunakan untuk mengetahui seberapa besar variabel independen mempengaruhi variabel dependen atau seberapa besar kontribusi variabel independen terhadap variabel dependen.

Tabel data 7: Hasil Uji Koefisien Determinasi Model Summary

\begin{tabular}{|c|c|c|c|c|c|c|c|c|}
\hline \multirow[b]{2}{*}{ Mode } & \multirow[b]{2}{*}{$\mathrm{R}$} & \multirow[b]{2}{*}{ R Square } & \multirow[b]{2}{*}{$\begin{array}{l}\text { Adjusted R } \\
\text { Square } \\
\end{array}$} & \multirow[b]{2}{*}{$\begin{array}{l}\text { Std. Error of } \\
\text { the Estimate }\end{array}$} & \multicolumn{4}{|c|}{ Change Statistics } \\
\hline & & & & & $\begin{array}{l}\text { R Square } \\
\text { Change }\end{array}$ & F Change & di1 & $\mathrm{df2}$ \\
\hline 1 & $759_{3}$ & .576 & .475 & 1.21072427E2 & .576 & 5.712 & 5 & 21 \\
\hline
\end{tabular}


Sumber: Output SPSS data yang diolah, 2018

Berdasarkan tabel di atas nilai R Square yakni 0,576 nilai tersebut menunjukkan bahwa variabel nilai perusahaan mampu dijelaskan oleh variabel X1 yakni pengungkapan akuntansi lingkungan,variabel X2 yakni kepemilikan saham sebesar 57,6 \% dan sisanya sebesar 42,4\% dijelaskan oleh variabel lain yang tidak diikutsertakan pada penelitian ini.

\section{Uji t Test}

Uji ini digunakan untuk mengetahui apakah pengaruh variabel independen terhadap variabel dependen bersifat menentukan atau tidak. Kriteria signifikan berdasarkan nilai signifikansi $<0,05$ maka variabel independen mempunyai pengaruh yang signifikan terhadap variabel dependen begitupun sebaliknya, jika nilai signifikansi $>0,05$ maka variabel independen tidak mempunyai pengaruh yang signifikan terhadap variabel dependen.

Tabel 8: Hasil Uji t test

Coefficients

\begin{tabular}{|c|c|c|c|c|c|c|c|}
\hline \multirow[b]{2}{*}{ Mods } & & \multicolumn{2}{|c|}{ Unstandardized Coefficients } & \multirow{2}{*}{$\begin{array}{c}\begin{array}{c}\text { Standardized } \\
\text { Coefficients }\end{array} \\
\text { Beta } \\
\end{array}$} & \multirow[b]{2}{*}{$t$} & \multirow[b]{2}{*}{ Sig. } & \multirow{2}{*}{$\begin{array}{c}95 \% \\
\text { Confidence } \\
\text { Interval for B } \\
\text { Lower Bound }\end{array}$} \\
\hline & & $\mathrm{B}$ & Std. Error & & & & \\
\hline \multirow[t]{6}{*}{1} & (Constant) & -141.855 & 71.372 & & -1.988 & .060 & -290.281 \\
\hline & $\begin{array}{l}\text { pengungkapan akuntansi } \\
\text { lingkungan }\end{array}$ & 478.244 & 173.930 & .492 & 2.750 & .012 & 116.537 \\
\hline & kepemilikan saham & 8.688 & 2.014 & .833 & 4.314 & .000 & 4.500 \\
\hline & moderasi1 & -7496.033 & 3370.440 & -.757 & -2.224 & .037 & -14505.247 \\
\hline & moderasi2 & -118.901 & 42.582 & -.613 & -2.792 & .011 & -207.455 \\
\hline & kinerja keuangan & 2224.390 & 965.732 & .832 & 2.303 & .032 & 216.042 \\
\hline
\end{tabular}

a. Dependent Variable: nilai perusahaan

Sumber: Output data yang di olah, 2018

a. Pengujian Hipotesis 1

H1 : Pengungkapan akutansi lingkungan berpengaruh signifikan terhadap nilai perusahaan.

Berdasarkan tabel 8 (delapan) didapatkan estimasi variabel pengungkapan akuntansi lingkungan sig sebesar 0,012 yakni $<0,05$ maka pengungkapan akuntansi lingkungan berpengaruh signifikan terhadap nilai perusahaan. Dengan demikian maka hipotesis 1 diterima. Arah koefisien regresi bertanda positif, hal ini menunjukkan bahwa setiap terjadi peningkatan pengungkapan akuntansi lingkungan maka akan meningkatkan nilai perusahaan.

Dilihat dari hasil pengujian hipotesis yang telah dilakukan dapat diketahui secara parsial pengungkapan akuntansi lingkungan berpengaruh signifikan terhadap nilai perusahaan. Hal ini menunjukkan bahwa pengungkapan akuntansi lingkungan memberikan pengaruh bagi peningkatan nilai perusahaan. Hipotesis yang diajukan menyatakan bahwa pengungkapan akuntansi lingkungan mempunyai pengaruh terhadap nilai perusahaan pada sub sektor kemasan dan plastik yang terdaftar di BEI terbukti kebenarannya. Berdasarkan uji $t$ statistik menunjukkan bahwa nilai sig dari pengungkapan akuntansi lingkungan sebesar 0,012 maka nilai tersebut dibawah 0,05 hal ini menunjukkan bahwa terdapat pengaruh signifikan pengungkapan akuntansi lingkungan terhadap nilai perusahaan.

b. Pengujian hipotesis 2

$\mathrm{H} 2$ : Kepemilikan saham berpengaruh signifikan terhadap nilai perusahaan.

Berdasarkan tabel 8 (delapan) hasil estimasi variabel kepemilikan saham diperoleh nilai signifikansi $0,000<0,05$ hal ini menunjukkan bahwa kepemilikan saham berpengaruh signifikan terhadap nilai perusahaan. Arah koefisien regresi bertanda positif, hal ini menunjukkan bahwa setiap terjadi peningkatan kepemilikan saham suatu perusahaan akan meningkatkan nilai perusahaan. 
Hasil pengujian menunjukkan bahwa kepemilikan saham berpengaruh signifikan terhadap nilai perusahaan.Hasil pengujia hipotesis sementara terbukti kebenarannya dengan hasil penelitian yang ditunjukkan bahwa kepemilikan saham berpengaruh signifikan terhadap nilai perusahaan. Hal ini bisa dilihat dari uji $\mathrm{t}$ test dimana nilai sig $<0,05$ hal ini menunjukkan bahwa kepemilikan saham memberikan pengaruh signifikan terhadap nilai perusahaan. Hal ini didukung oleh penelitian dari Ekayana (2008), Taswan (2008), dan Soliha (2009) yang menunjukkan hasil bahwa kepemilikan saham berpengaruh terhadap nilai perusahaan, bahwa manajemen perlu menyusun struktur dan komposisi kepemilikan saham yang optimal agar dapat memberikan kontribusi terhadap peningkatan nilai perusahaan.

\section{c. Pengujian hipotesis 3}

H3 : Pengungkapan akuntansi lingkungan berpengaruh signifikan terhadap nilai perusahaan mampu di moderasi kinerja keuangan.

Berdasarkan tabel 8 (delapan) menunjukkan bahwa nilai sig sebesar $0,037<0,05$ hal ini menunjukkan bahwa kinerja keuangan mampu memoderasi pengaruh pengungkapan akuntansi lingkungan terhadap nilai perusahaan, arah koefisien regresi bertanda negatif, hal ini menunjukkan bahwa pengungkapan akuntansi lingkungan terhadap nilai perusahaan mampu dimoderasi oleh kinerja keuangan tetapi memperlemah hubungan antara pengungkapan akuntansi lingkungan terhadap nilai perusahaan.

Dilihat dari Hasil pengujian hipotesis yang telah dilakukan menunjukkan bahwa terdapat pengaruh pengungkapan akuntansi lingkungan terhadap nilai perusahaan mampu dimoderasi oleh kinerja keuangan tetapi memperlemah hubungan antar variabel. Dari hasil hipotesis sementara terbukti kebenarannya karena setelah melakukan pengujian hasil penelitian ini menunjukkan bahwa kinerja keuangan mampu memoderasi pengungkapan akuntansi lingkungan terhadap nilai perusahaan. Hal ini ditunjukkan oleh tabel t test yakni sig 0,037 dimana kurang dari 0,05 yang menunjukkan bahwa kinerja keuangan mampu memoderasi pengungkapan akuntansi lingkungan terhadap nilai perusahaan.

\section{d. Pengujian hipotesis 4}

H4 : Kepemilikan saham berpengaruh signifikan terhadap nilai perusahaan mampu di moderasi kinerja keuangan.

Berdasarkan tabel 8 (delapan) menunjukkan nilai sig sebesar $0,011<0,05$ hal ini menunjukkan bahwa kinerja keuangan mampu memoderasi pengaruh kepemilikan saham terhadap nilai perusahaan, arah koefisien regresi bertanda negatif, hal ini menunjukkan bahwa kepemilikan saham terhadap nilai perusahaan mampu di moderasi oleh kinerja keuangan tetapi memperlemah hubungan antara kepemilikan saham terhadap nilai perusahaan.

Berdasarkan hasil penelitian ini menunjukkan bahwa kinerja keuangan mampu memoderasi kepemilikan saham terhadap nilai perusahaan. Dimana hal ini dapat dilihat dari tabel uji t test nilai sig 0,011 <0,05 ini menunjukkan bahwa kepemilikan saham mampu memoderasi kepemilikan saham terhadap nilai perusahaan. Untuk arah koefisien regresi bertanda negatif maka kepemilikan saham terhadap nilai perusahaan mampu di moderasi oleh kinerja keuangan tetapi memperlemah hubungan antara kepemilikan saham terhadap nilai perusahaan. Penelitian ini tidak sejalan dengan penelitian Kusuma, (2011) dengan judul pengaruh kepemilikan saham terhadap nilai perusahaan dengan kinerja keuangan dan kebijakan hutang sebagai variabel intervening. Dengan hasil penelitian bahwa tidak ada pengaruh antara struktur kepemilikan pada nilai perusahaan melalui kinerja keuangan. 


\section{E. PENUTUP}

Berdasarkan hasil penelitian tersebut diatas, dapat disimpulkan bahwa pengungkapan akuntansi lingkungan berpengaruh signifikan terhadap nilai perusahaan. Berdasarkan uji $t$ statistik menunjukkan bahwa nilai sig dari pengungkapan akuntansi lingkungan sebesar 0,012 maka nilai tersebut dibawah 0,05 hal ini menunjukkan bahwa terdapat pengaruh signifikan pengungkapan akuntansi lingkungan terhadap nilai perusahaan.

Kepemilikan saham juga berpengaruh signifikan terhadap nilai perusahaan.Hal ini bisa dilihat dari uji t test dimana nilai sig $<0,05$ hal ini menunjukkan bahwa kepemilikan saham memberikan pengaruh signifikan terhadap nilai perusahaan.

Variabel Kinerja keuangan terbukti mampu memoderasi pengungkapan akuntansi lingkungan terhadap nilai perusahaan, tetapi memperlemah hubungan antara pengungkapan akuntansi lingkungan terhadap nilai perusahaan. Dimana hal ini dapat dilihat dari tabel uji t test nilai sig 0,011<0,05 ini menunjukkan bahwa kepemilikan saham mampu memoderasi kepemilikan saham terhadap nilai perusahaan. Untuk arah koefisien regresi bertanda negatif maka kepemilikan saham terhadap nilai perusahaan mampu di moderasi oleh kinerja keuangan tetapi memperlemah hubungan antara kepemilikan saham terhadap nilai perusahaan.

Untuk variable Kinerja keuangan mampu memoderasi kepemilikan saham terhadap nilai perusahaan, tetapi memperlemah hubungan antara kepemilikan saham terhadap nilai perusahaan.Dimana hal ini dapat dilihat dari tabel uji t test nilai sig 0,011<0,05 ini menunjukkan bahwa kepemilikan saham mampu memoderasi kepemilikan saham terhadap nilai perusahaan. Untuk arah koefisien regresi bertanda negatif maka kepemilikan saham terhadap nilai perusahaan mampu di moderasi oleh kinerja keuangan tetapi memperlemah hubungan antara kepemilikan saham terhadap nilai perusahaan.

Dari simpulan diatas, disarankan kepada pihak-pihak terkait, untuk memperhatikan variable tersebut diatas guna pengambilan kebijakan di tingkat manajemen perusahaan.

\section{DAFTAR PUSTAKA}

Analisis Moderating. 2015. Available at https://dinus.ac.id $>$ repository $>$ doc. 19 Mei 2018

A, Prayudah. 2015. ”Pengertian Kinerja Keuangan”. https://eprints.polsri.ac.id.6 April 2018

A,Tiara. 2017. ”Analisis Rasio Keuangan”. https://eprints.polsri.ac.id. 8 April 2018

A, Yoshi. 2011. "Peran Akuntansi Lingkungan Dalam Meningkatkan Kinerja Keuangan”. https://repository.wima.ac.id. 25 Maret 2018

Budi, Kho. 2017. "Pengertian ROA dan Rumus ROA". https://ilmumanajemenindustri.com. 10 April 2018

DM, Ningsih. 2014. "Metodologi Penelitian". https://etheses.uinmalang.ac.id. 25 Maret 2018

ED, Sulistiyaningsih. 2017. "Pengaruh Kepemilikan Manajerial dan Profitabilitas Terhadap Nilai Perusahaan". https://ejournal.stiesia.ac.id. 14 April 2018

G, Agung. 2012. "Pengertian Kinerja Keuangan”. https://eprints.uny.ac.id. 6 April 2018

Indrianto, Nur. 2015. ”Objek dan Metode Penelitian”. https://elib.unikom.ac.id. 10 Mei 2018

JAD: Jurnal Riset Akuntansi dan Keuangan Dewantara

Vol. 1 No. 2, Desember 2018

https://ejournal.stiedewantara.ac.id/index.php/JAD/issue/view 
Kurnia, Nia. 2008. "Pengertian Saham Dan Jenis Saham". https://eprints.polsri.ac.id. 10 April 2018

Makori, Daniel Mokaga. " Environmental Accounting and Firm Profitability". www.ijhssnet.com>journal. 14 Maret 2018

Meilinda, FI dan Bertha S. Sutejo. 2012. "Interdepensi Kepemilikan Manajerial dan Kepemilikan Institusional serta pengaruhnya terhadap Kinerja Keuangan. Journal Manajemen dan Bisnis". https://www.wawasanpendidikan.com. 9 Mei 2018

M, Hidayat. 2016. "Perkembangan Green Accounting dan Penerapan Green Accounting”. https://opini.unrika.ac.id>article. 22 Mei 2018

MR, Andriyanto. 2012. "Penggunaan Istilah Green Accounting". https://eprints.ums.ac.id. 28 April 2018

NPWP, Damayanti. 2014. "Pengaruh Kepemilikan Manajerial dan Institusional pada Nilai Perusahaan". https://ojs.unud.ac.id>article. 19 April 2018

Nur'ainun, Unun. 2017. "Pengungkapan Akuntansi Lingkungan dan kinerja Keuangan”. http://repository.widyatama.ac.id. 15 Maret 2018

Nursalim, Muhammad. 2014. "Penelitian Kuantitatif dan Kualitatif". https://muhammadnursalim.unesa.ac.id. 17 April 2018

Nur Sari, Enggar. 2017. "Analisis Pengungkapan Lingkungan Terhadap Kinerja Keuangan dan Kinerja Saham". http://ejurnal.stimata.ac.id. 15 Maret 2018

Nuruzzakiah. 2014. "Metodologi Penelitian." https://etheses.uinmalang.ac.id. 25Maret 2018

N, Aisyiah. 2013. "Pengukuran Kinerja Perusahaan”. https://media.neliti.com. 14 Mei 2018

Priyadi, Devia. 2016. "Makalah Akuntansi Lingkungan". https://www.academia.edu>makalah akuntansi lingkungan. 18 April 2018

R Kusumaningtias. 2013. "Green Accounting, Mengapa dan Bagaimana". https://publikasiilmiah.ums.ac.id. 14 Mei 2018

R Pahlevi. 2013. "Pengukuran Kinerja Keuangan Perusahaan". https://media.neliti.com>publication. 14 Mei 2018

Sudirno. 2014. "Pengaruh Pencapaian Profitabilitas, Tingkat Leverage dan Prosentase Kepemilikan Manajemen Terhadap Pengungkapan Informasi Akuntansi Lingkungan”. http:// Journal.stembi.ac.id. 5 Mei 2018

Sawitri, Aristha Purwanthari. 2017. "Analisis Pengaruh Pengungkapan Akuntansi Lingkungan dan Kinerja Lingkungan Terhadap Nilai Perusahaan”. 8 Mei 2018 
Sujoko dan Soebiantoro, ugy. 2007. "Pengaruh Kepemilikan Saham, Leverage, Faktor Intern dan Faktor Ekstern Terhadap Nilai Perusahaan”. https://jurnalmanajemen.petra.ac.id. 9 Mei 2018

Sukma, Devani. 2011. "Peran dan Fungsi Akuntansi lingkungan". https://keungan.com.peran dan fungsi akuntansi lingkungan. 10 April 2018

SR Purnamasari. 2013. "Pengertian Nilai Perusahaan". https://repositorywidyatama.ac.id. 2 Mei 2018

Simfoni, Dawai. 2011. "Pengujian Asumsi Klasik Model Regresi Berganda". https://dawaisimfoni.wordpress.com. 29 April 2018

Widjaja, Laurensia Meilinda Kusuma. 2014. "Pengaruh Struktur Kepemilikan Saham Terhadap Kinerja Perusahaan”. http://repository.wima.ac.id. 12 Mei 2018

W Budianto. 2014. "Pengaruh Kepemilikan Manajerial Terhadap Nilai Perusahaan”. https://e-journal.unipma.ac.id. 4 April 2018 